\title{
PROFESSIONAL PLACEMENT SERVICE 1993 ANNUAL MEETING
}

APSA will sponsor a Professional Placement Service at the Washington Hilton Hotel in Washington, DC, during the 1993 Annual Meeting. The Placement Service will be open from 8:00 a.m. to 6:00 p.m. on Thursday thru Saturday, September 2-4; and from 9:00 a.m. to Noon on Sunday, September 5.

Facilities will be available for reviewing listings, exchanging messages, and interviewing. To obtain Placement Service forms for listing vacancies (Employer Forms) or applications (Candidate Forms), please complete and mail the attached form as soon as possible but no later than July 26, 1993. Employer and/or Candidate forms will be forwarded to you upon receipt of your request.

CANDIDATES WHO ARE NOT PRE-REGISTERED WILL BE CHARGED AN ON-SITE REGISTRATION FEE OF $\$ \mathbf{1 0 . 0 0}$. Employers whose Departments are not members of the APSA Departmental Services Program will be charged a Registration Fee of $\$ 100.00$ (PREPAID). All persons using the Placement Service are required to register for the 1993 Annual Meeting.

PRE-CONVENTION REGISTRATION IS STRONGLY RECOMMENDED. EMPLOYERS AND CANDIDATES FILING IN ADVANCE OF THE MEETING WILL RECEIVE EXPEDITED SERVICE.

Name:

Mailing Address:

City:

State: Zip:

Organization or Department:

Candidate $\square$ Employer Number of Positions

Mail to:

1993 Annual Meeting Professional Placement Service American Political Science Association

1527 New Hampshire Avenue, N.W.

Washington, D.C. 20036 